\title{
A Deficiency of Donors or an Abundance of Barriers? Title IX Fundraising Challenges from the Perspective of Athletic Department Fundraisers
}

\author{
Matt R. Huml ${ }^{1}$, Katie M. Brown'르. Mathew J. Bergman ${ }^{3}$ \\ ${ }^{1}$ University of Cincinnati, ${ }^{2}$ Texas Tech University, and ${ }^{3}$ University of Louisville
}

This paper explores how athletic development personnel perceive the influence of Title IX within athletic fundraising, particularly how fundraisers view the interests of donors and barriers that are created for non-football/men's basketball programs. Using distributive justice as a theoretical lens, we examined the perspectives of athletic department fundraisers working at NCAA, Power Five athletic departments. Interviews from participants gleaned insights into only meeting the minimum legal requirements of Title IX, fighting between non-revenue programs for remaining resources, elevated requirements for program success for non-football/men's basketball programs, and more. This paper provides insight into a distinct context of fundraising, which often avoids Title IX scrutiny, but is the primary source for athletic departments to raise additional funds for their sport programs.

Keywords: Title IX, College Athletics, Fundraising

There is a constant struggle for Olympic sports to receive the same level of resources and facility improvements that are provided for football and men's basketball (Francis, 2016; Rubin \& Lough, 2015). Universities are often willing to substantially increase funding for football and men's basketball for a litany of reasons, such as hiring a new coaching staff, keeping up with rivals, or even trying to increase on-field success (Huml, Pifer, Towle, \& Rode, 2019). When resources are not reciprocated to other sports, different and more challenging requirements may be created before the university is willing to increase budgets and begin fundraising initiatives to support these programs. This creates a disadvantage for sports outside of football and men's basketball and is especially challenging for female sports.

Title IX (20 U.S.C. $§ 1681)$ provides equal access to any program or activity that receives Federal financial assistance, but critiques have been levied about the lack of Title IX oversight pertaining to certain resources, such as coaching salaries (Thelin, 2000). While coaching salaries are often publicly available, concerns are raised about other funding sources that are either private or informal. Some examples include fundraising efforts, and how such efforts are shaped and influenced to better 
support football and men's basketball to the detriment of women's sport programs. Title IX and fundraising are important areas of future study within sport for a number of reasons. With philanthropy to universities at an all-time high, but women's sports receiving so little of these donations (Longman, 2019), the current context raises important questions on why there is such a disparity among contributions. Understanding whether barriers are external (i.e., lack of donor interest) or internal (athletic departmental politics) or both would create important insight into non-revenue-generating sports, fundraisers, and athletic departments as it relates to complying with Title IX. Lastly, revenue generation has been previously mentioned as a "blind spot" for Title IX (Grimmett-Norris, 2015); there is a need to examine this oversight and detail any disparities that may occur, such as fundraising disparities.

Philanthropy is one of the leading sources of athletic department revenue, and currently there is a dearth of research regarding philanthropy and Title IX in sport. The purpose of this paper is to explore the perception of Title IX by athletic department fundraisers. Specifically, we investigate how athletic fundraisers work with prominent athletic donors in guiding or restricting their donations towards specific sport programs or prioritized projects.

\section{Literature Review}

\section{Distributive Justice}

Organizations have finite resources that may be distributed to the various programs and departments in order to operate (Friedman, Parent, \& Mason, 2004). Deciding how to distribute these resources can be complex and troublesome for budgetary managers. As context for this article, the theory of distributive justice has largely been defined as the principle underlying the distribution of resources and the outcomes and rewards to separate parties in an organization (Hums \& Chelladurai, 1994). The three key principles of distributive justice are: need, equity, and equality (Deutsch, 1975a).

In need-based distributions, the organizations who exhibit the greatest need for resources are allocated the largest portion of resources or receive the smallest reductions (Deutsche, 1975b). Mahony, Hums, and Reimer (2005) identified three ways for determining need: (a) Those with less of a resource can be perceived as having the greatest need, (b) other groups may be deemed more needy if their unit has higher costs due to the nature of the activity, and (c) maintaining a competitive foothold may be more costly in their area than with others. When apportionments are made on the basis of equity, distributors allocate resources based on contribution to the organization (Törnblom, Jonsson, \& Foa, 1985). This means individuals or groups who contribute more will receive a larger input, or the perceived equivalent amount of their contribution (Dixon, Turner, Pastore, \& Mahony, 2003). On the basis of equality, groups and individuals receive an equal allocation regardless of contribution. Törnblom et al. (1985) noted the principles of equality include: (a) equality of treatment, (b) equality of results over the long term, and (c) an equal opportunity to receive distributions. Equality of treatment means the distributions are dispersed 
equally in a given situation, while equality of results over the long term indicates distributions are equal over a period of time. Under equal opportunity, everyone has an equal chance to receive resources but scholars have rejected this notion in other settings (Mahony, Hums, \& Reimer, 2002; Mahony \& Pastore, 1998).

\section{Title IX}

Title IX of the Education Amendments of 1972 prohibits discrimination on the basis of sex in federally funded education programs or activities (20 U.S.C. $\S 1681$ ). However, it is important to note that sport was not originally included in the amendment. In 1974, a proposal to exempt sports that produced gross revenue or donations from Title IX compliance determinations was rejected in Congress. In response, a separate amendment was passed by Congress to expand the protection to intercollegiate athletics (Edwards, 2010). However, in 1978, the Department of Health, Education, and Welfare received roughly 100 discrimination complaints against athletic departments at more than 50 institutions of higher education, which prompted the Department to provide further guidance regarding compliance with Title IX in intercollegiate athletic programs and a framework for conflict resolution (Office of Civil Rights, U.S. Department of Health, Education, and Welfare, 1979). The Title IX 1979 Policy Interpretation applies to three areas: financial assistance to athletes; program areas that provide treatment, benefits, and opportunities for the athletes; and providing equally effective accommodation of the interests and abilities of male and female athletes (Office of Civil Rights, U.S. Department of Health, Education, and Welfare, 1979). The financial assistance requirement, or scholarships, means assistance should be available on a substantially commensurate basis to the number of male and female participants in the institution's athletic program. Pursuant to the regulation, compliance in other program areas refers to the governing principle that male and female athletes should receive equivalent treatment, benefits, and opportunities. Lastly, regarding compliance in meeting the interests and abilities of male and female students, the regulation states athletic interests and abilities of male and female students must be equally effectively accommodated (Office of Civil Rights, U.S. Department of Health, Education, and Welfare, 1979).

Sport scholars have previously investigated managerial decisions regarding resource allocations as it pertains to Title IX (Hums \& Chelladurai, 1994; Kim, Andrew, Mahony, \& Hums, 2008; Mahony \& Pastore, 1998; Mahony, Riemer, Breeding, \& Hums, 2006; Rubin \& Lough, 2015). Women often favor the equality principle for distribution of resources between programs, compared to men who favor the equity principle (Hums \& Chelladurai, 1994; Patrick, Mahony, \& Petrosko, 2008). The equity principle becomes problematic for women's sports because the popularity and growth of women's sport was achieved without an increase in coverage of women's sports on-campus or in the surrounding community (Cooky, Messner, \& Hextrum, 2015). With women's sports not receiving the same marketing increase as men's sports, it creates a disadvantage within an equity approach of resource distribution. Need-based distribution can also create a disadvantage for women's sports because athletic departments will perceive need compared to what other universities provide 
for each sport (Cunningham \& Sagas, 2005; Mahony \& Pastore, 1998). For example, if a university provides its football program with $\$ 10$ million in yearly support, another university may believe its football program needs $\$ 10$ million in order to compete. Similar support for women's sports is not reciprocated, as current female administrators spoke to ignorance of applying the need principle to women's sports when they were competing as student-athletes during Title IX's infancy (Rubin \& Lough, 2015). Rubin and Lough (2015) provided examples of a lack of resources for women's sports, such as not providing basic playing equipment like leather basketballs for the basketball team or access to medical supplies. With concerns about the need and equity principles, current female athletes and, surprisingly, male athletes in revenue sports believed distributing resources based on the equality principle would be the fairest approach (Kim et al., 2008). On the contrary, other studies have found male athletes in non-revenue sport programs to support resource distribution to support revenue programs, even at the detriment of their own programs (Messner \& Solomon, 2007). These findings highlight the possibility of differing opinions based on revenue sport designation. An important consideration for resource distribution is athletic department fundraising, which can fluctuate on a variety of factors but also provides the athletic departments funds that are unencumbered by university administration and provide athletic administrators greater flexibility on how they are used.

\section{Athletic Fundraising}

Coaching salaries continue to rise, and the costs of keeping up with the "arms race" regarding programs, facilities, and other expenses is likely unsustainable (Frank, 2004; Huml et al., 2019; Sparvero \& Warner, 2013). Most intercollegiate athletic departments in the US report losses or are bound to operate within specific budget parameters (Sanderson \& Siegfried, 2017). As a result, with athletic departments striving for self-sufficiency, donations have been identified as an opportunity for increasing revenue. Athletic fundraising is often viewed as one of the last mainstays of limitless financial support for intercollegiate athletic programs (Stinson \& Howard, 2007), and many schools have become reliant on fundraising support to maintain operations (NCAA, 2018a). For college athletic programs to achieve long-term sustainability, financial support from donors is crucial (Park, Ko, Kim, Sagas, \& Eddosary, 2016). Athletic fundraising has also steadily increased over the years, as donors are becoming more likely to be tapped to support capital campaigns and large facility projects (Huml et al., 2019).

Much of the literature on fundraising in intercollegiate athletics has focused on donor motivations and intentions (e.g., Brunette, Vo, \& Watanabe, 2017; Gladden, Mahony, \& Apostolopoulou, 2005; Ko, Rhee, Walker, \& Lee, 2014; Park et al., 2016). There exists a range of motivations for donors to contribute to athletic programs: opportunities for priority seating, fan identification, athletic event attendance, complimentary programs, public recognition, hospitality suites, access to insider information, priority tickets for away games and bowl games, alumni status, tax deductions, special treatment, philanthropy, and successful football teams (Gladden et al., 2005; Mahoney, Gladden, \& Funk, 2003; Stinson \& Howard, 2004, 2010). Research 
has shown football to be the primary influence on giving at institutions who have football teams (Martinez, Stinson, Kang, \& Jubenville, 2010). While football may be a driving force for donations, gift officers for universities must work to comply with Title IX requirements while also managing donor motivations and intentions. Thus, it is imperative to understand how these athletic fundraisers guide donations within the university athletic departments, with respect to Title IX.

Fundraising provides a distinct context for examining Title IX, which has rules regarding access to educational opportunities. When creating new facilities, public institutions need to reflect on how those facilities will provide for both male and female athletes. For example, an eager donor may want to create a locker room for the men's golf team. Title IX considerations would require the athletic department to consider the women's golf team and its current options for a locker room. If the donation is not earmarked for new facilities, the athletic department may be able to avoid Title IX oversight, such as a donation that funds team travel for the men's golf team but not for the women's golf team.

\section{Method}

Therefore, the purpose of this paper is to explore the perception of Title IX by athletic department fundraisers. Specifically, we examine how athletic fundraisers work with prominent athletic donors in guiding or restricting their donation towards specific sport programs or prioritized projects. This study utilized a qualitative design to explore the interaction of gift officers with decision makers within the athletic department (i.e., athletic director) and donors to guide their decision-making through the lens of Title IX. Our two hypotheses were:

1. Athletic fundraisers believe there is a reluctance of donors to support varsity sport programs outside of football and men's basketball.

2. Athletic fundraisers create barriers for varsity sports programs outside of football and men's basketball to receive increased resources alongside placing priority on athletic facility projects.

To assess these guiding questions, we used the Gioia methodology to capture the unique context of the interaction of fundraisers with donors and university leadership, while also generating concepts to connect their responses to the theory of distributive justice. The Gioia methodology has been used to preserve informant perspectives while bridging to generalizable theoretical concepts (Gioia, Corley, \& Hamilton, 2012; Gioia \& Thomas, 1996). This methodology requires the researcher to analyze the informant's statements by developing first-order concepts that accurately characterize the informant's context and vocabulary (Gioia \& Chittipeddi, 1991). These informant-centric terms are then analyzed through a second phase of the reviewers comparing each other's analysis and reconciling any differences, known as second-order concepts, which are categorized as researcher-centric terms and dimensions (Gioia et al., 2012). These second-order concepts provide a connec- 
tion between informant responses and abstract theoretical principals. This qualitative approach provides strengths to the researcher for applying theoretical concepts to applications that can be generalizable to practitioners (Gioia \& Chittipeddi, 1991).

The Gioia methodology is also suited for answering our hypotheses for further reasons. First, it is useful for developing theory, but it does not establish or create theory as with grounded method approaches (Gioia et al., 2012). In this article, we assume that distributive justice theory accurately portrays the varying ways of how managers distribute resources among groups. The questions we focused on were: (a) how employees charged with raising funds for the athletic department may influence their manager's or donor's decisions for resource distribution, (b) how established distributive justice approaches were thematically aligned with athletic fundraiser responses, and (c) how Title IX shaped the fundraiser's responsibilities and actions within the athletic department. Second, our methodological approach aligns well with our choice to study the distinctive case of college athletics fundraising (Flyvbjerg, 2006). Scholars use distinct cases to test and progress a theory by selecting a particularly trying, dramatic, or information-rich situation (such as athletic fundraising for college athletics, where donors and internal stakeholders are deciding which project to prioritize to help their various sport programs), so that new insights can be developed, which can then be tested in simpler situations. Examining Title IX within college athletics is not a unique contribution to the field, but the perspective of athletic fundraising and influencing projects from the perspective of Title IX and revenue/non-revenue sport is a distinct approach within scholarship. The Gioia method allows us to study a distinct case because it maintains the uniqueness while linking it to abstract generalizable concepts, such as distributive justice.

\section{Participants}

We targeted a sampling frame of athletic fundraisers at predominantly NCAA Power Five, Division I athletic departments. This targeted population was chosen for multiple reasons. First, Power Five, Division I athletics represents the highest level of intercollegiate sport competition and corresponds with significant fundraising commitments from fans and local constituents. Second, Power Five, Division I athletic departments also support the most amount of varsity sports, with the NCAA requiring a minimum of 16 varsity sport programs to maintain status as a Division I Football Bowl Subdivision (FBS) athletic program (NCAA, 2018b). While their profitability is often scrutinized by scholars (Cheslock \& Knight, 2015), athletic departments are often dependent on donations to construct and maintain new athletic facilities (Huml et al., 2019). This fundraising is vital and differs across the NCAA divisions, as Power Five athletic departments are able to secure millions in yearly donations, and are therefore able to support multiple projects simultaneously. This differs from smaller athletic departments, which have fewer varsity sports and a smaller donor base, thus they may be only able to target one fundraising project every couple of years. Therefore, Power Five athletic departments have the affluence and capacity to support projects for both revenue (e.g., football) and nonrevenue (e.g., lacrosse) programs.

We interviewed 19 athletic administrators at 18 different NCAA Division I uni- 
versities in the United States (one interview involved two athletic administrators working at the same institution). We used a snowball sampling method, first by purposely seeking out all fundraisers within a prominent Power Five conference, with additional institutions sought because of unique athletic department settings, such as a new athletic director or Division I program without football. Each administrator contacted was involved within development, the traditional office within an athletic department that is responsible for fundraising. Athletic fundraisers work as the go-between for internal stakeholders (interests from coaches, student-athletes, athletic directors, university leadership) and external stakeholders (donors and local community) by providing information and shaping interests that work for both parties. With their influence on decision making for both parties, they provide important context within the topic of Title IX project support. All of the participants responded and agreed to an interview, although one university later requested to be removed from the study, which reduced our sample to 18 usable interviews (two of the participants did a combined interview, leaving a total of 19 participants). The participants' characteristics are summarized in Table 1.

\section{Data Collection and Analysis}

Before conducting interviews, we developed an interview guide with a committee of three scholars with expertise in intercollegiate athletics (both as former athletes and administrators) and two practitioners who work in athletic department fundraising. The interview guide was created to elicit perspectives from fundraisers on their job and interactions with donors, while also being tailored to the context of athletic departments and using the terms that administrators use (Gioia et al., 2012). A third athletic fundraising practitioner vetted the final interview guide. She agreed that all topics and questions were appropriate but recommended adding a topic about "quid pro quo" gifts (whereby donors request benefits from the athletic department in exchange for their donation) because these requests are an important part of donor management at major universities. We also added a question about the new federal tax plan that was introduced mid-way through the interview process, because this tax plan — which removed deductions for charitable giving - was expected to change how athletic departments worked with donors (Tax Cuts and Jobs Act, 2017). Because this change occurred during data collection, only a portion of the participants were solicited on the topic.

Our analysis strategy began by reviewing literature on distributive justice theory and Title IX. This initial review focused on defining responses from fundraisers on their interactions with donors, internal decision-makers, and project prioritization within the concepts of need, equity, and equality. This analysis was completed using the open coding approach consistent with Gioia methodology (Gioia et al., 2012). This process is done in two-steps: (1) an establishment of first-order codes that are abbreviation content titles based on quotes from the participants, and (2) second-order codes that theoretically connect the first-order codes to provide abstract insights that connect the study's context and theoretical framework). 
Table 1

Study participants

\begin{tabular}{|c|c|c|c|}
\hline Name & Title & NCAA & $\begin{array}{l}\text { Geographic } \\
\text { Location }\end{array}$ \\
\hline Phillip & Deputy Director of Athletics & Non-Power Five & South \\
\hline Jacob & Assoc. Athletic Director & Power Five & South \\
\hline Derek & $\begin{array}{l}\text { Asst. Athletic Director of } \\
\text { Development }\end{array}$ & Non-Power Five & West Coast \\
\hline Lewis & Executive Assoc. Athletic Director & Power Five & Southeast \\
\hline Melanie & $\begin{array}{l}\text { Assoc. Athletic Director of } \\
\text { Development }\end{array}$ & Power Five & Midwest \\
\hline Gregory & Senior Assoc. Athletic Director & Power Five & Midwest \\
\hline George & Senior Assoc. Athletic Director & Power Five & Midwest \\
\hline Kendall & $\begin{array}{l}\text { Senior Assoc. Athletic Director of } \\
\text { Development }\end{array}$ & Power Five & Midwest \\
\hline Nathan & $\begin{array}{l}\text { Assoc. Vice President for } \\
\text { Development }\end{array}$ & Power Five & Midwest \\
\hline Emilio & $\begin{array}{l}\text { Asst. Athletic Director of } \\
\text { Development }\end{array}$ & Power Five & Midwest \\
\hline Scott & $\begin{array}{l}\text { Asst. Athletic Director of } \\
\text { Development }\end{array}$ & Power Five & South \\
\hline Aaron & Assoc. Director of Development & Non-Power Five & South \\
\hline Brad & $\begin{array}{l}\text { Assoc. Athletic Director of } \\
\text { Development }\end{array}$ & Power Five & South \\
\hline Donovan & Director of Major Gifts & Power Five & South \\
\hline Brandon & Senior Assoc. Athletic Director & Power Five & South \\
\hline Shawn & President/CEO of Foundation & Power Five & South \\
\hline Brittany & $\begin{array}{l}\text { Senior Assoc. Athletic Director of } \\
\text { Development }\end{array}$ & Power Five & South \\
\hline Robert & $\begin{array}{l}\text { Senior Assoc. Athletic Director of } \\
\text { Development }\end{array}$ & Non-Power Five & West Coast \\
\hline Luke & Senior Assoc. Athletic Director & Power Five & Northeast \\
\hline
\end{tabular}

The first author scheduled, conducted, and recorded 13 interviews in person at the participants' offices and five interviews over the phone. This author has six years' experience in college athletics and was able to adopt an insider perspective during the interviews, which enabled them to ask pertinent follow-up questions and elicit details from the informants. The second author adopted an outsider perspective, pro- 
viding a legal acumen to Title IX considerations and balancing the insights from the first author. In total, 703 minutes of interviews were used in analysis, resulting in 237 single-spaced pages of transcripts. Interview times ranged from 35 minutes to one hour. Interviews were immediately transcribed and returned to the authors for edits and clarification. Following transcription, the completed transcripts were provided to the participants for review to ensure accuracy of transcription. Only one participant requested any edits, with those changes isolated to clarification of wording.

The first author and the second author conducted coding separately. The first author completed a thorough review of quotes from each participant interview, leading to the initial establishment of 450 concepts. Following this initial coding, the second author was provided these initial concepts, with both authors now required to review the quotes and concepts and create themes. This reduced total first-order concepts to 11 themes for the first author and nine themes for the second author. The first and second authors then compared their corresponding first-order concepts and themes: they agreed on 10 of 11 of the themes, covering $91 \%$ of the data. They discussed the differences and came to mutual agreement on the underlying data structure, which is represented in Figure 1.

\section{Results}

\section{Overview}

Our results indicate that Title IX affected the perspective of fundraisers. These influences included finding ways to simply meet the minimum legal requirements of Title IX to turning down monies because it would put them in weak Title IX legal standing. Fundraisers also spoke to the hurdles and elevated standards they placed on non-football and men's basketball programs, including fending Olympic sports against each other, pushing Olympic sports to be "cheerleaders" for football and men's basketball, claiming a lack of support from donors, and claiming a need for a national championship before women's sports would be eligible for improved facilities.

\section{Coaching Requests/Comparisons}

An important component stemming from the interviews was the involvement of coaches in deciding what projects should be considered. Head coaches had the opportunity to meet with their athletic director and development office annually to discuss needs for their program. Many of these requests are made by coaches in order to improve their team success and all requests are considered. One athletic fundraiser provided an overview of request options:

What your coach thinks is important for his program to win or her program to win, cause every coach has a different set, some coaches believe in, you know, I need the latest state-of-the-art locker room and weight room and training facility, and nutrition facility. And some other coaches say, I need a better competition facility, so it's kinda the eye of the beholder. (Gregory) 


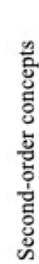

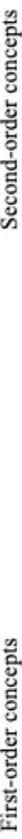
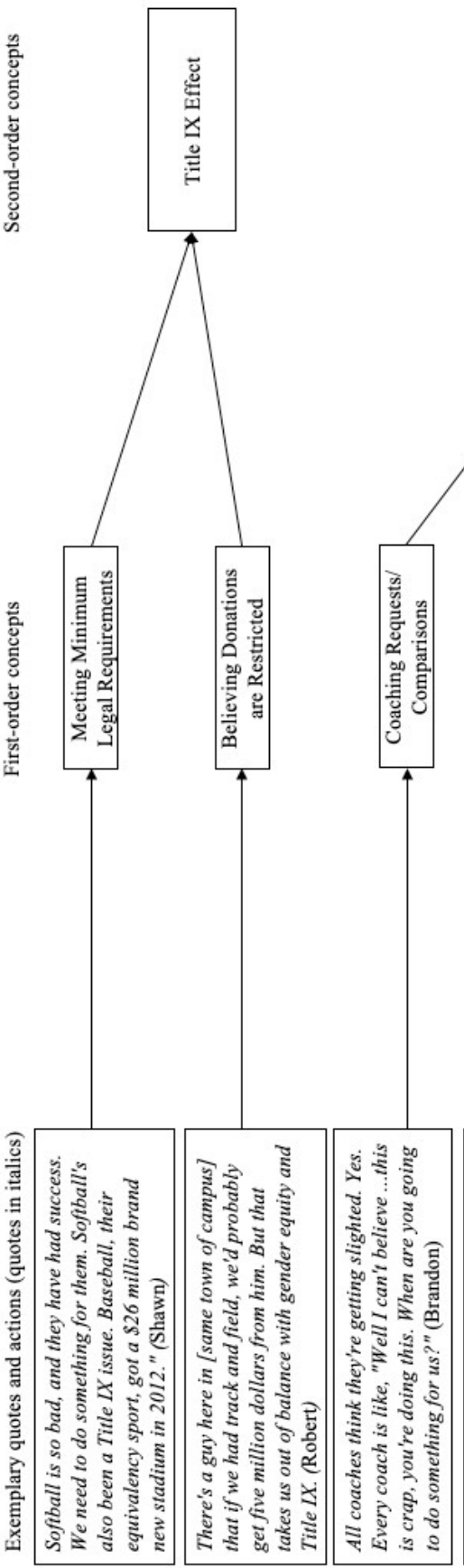

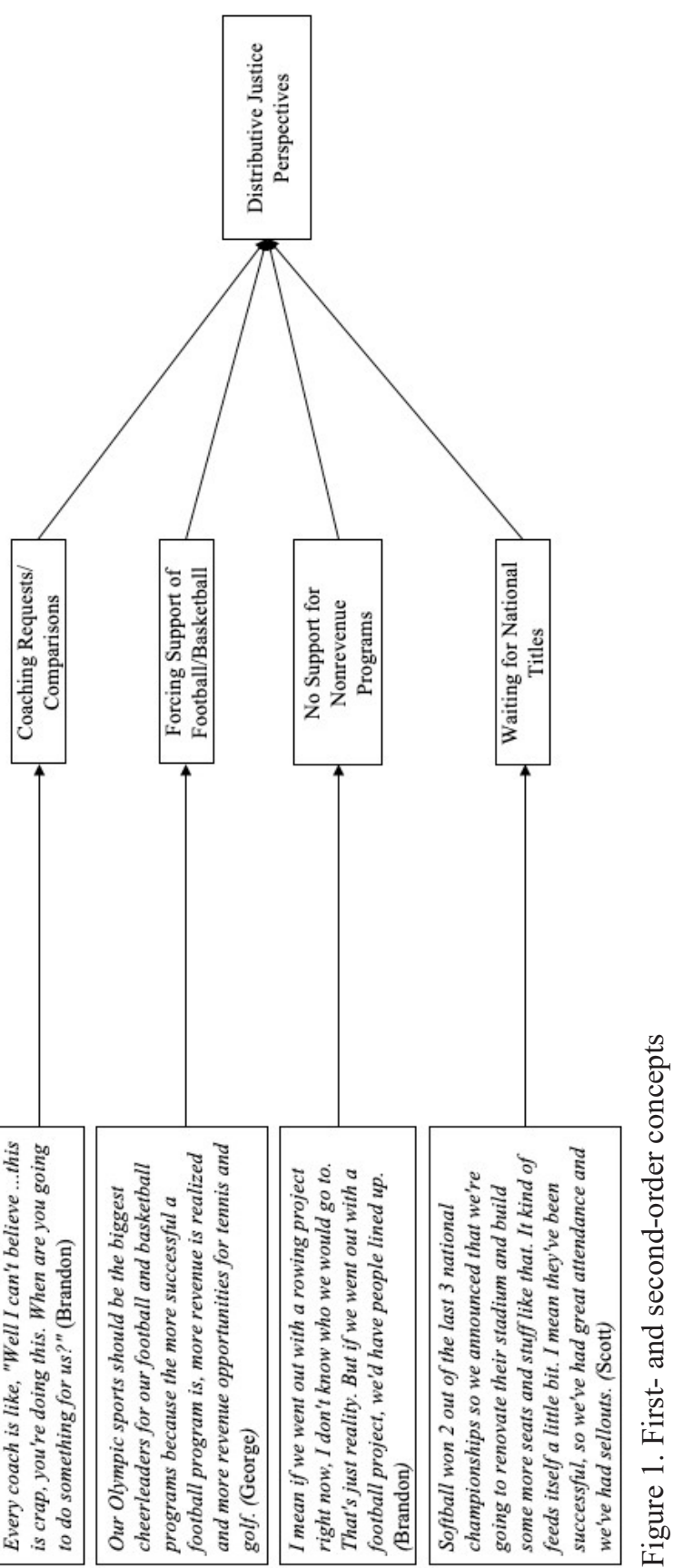


These requests are made by every coach in the athletic department: "Every sport has something they want to do to their facilities" (Scott). This requires the athletic director and development office to decide on which projects deserve to be prioritized to donors.

Coaches are aware of this competition for donor dollars and often go into the meeting with justification and data on why their requests should be supported. Many coaches keep close watch on the facility improvements being completed at their competitor schools, who then use these competitor upgrades as an explanation on why their project should be strongly considered: "For sure our coaches are doing that [keeping track of competitors]" (Scott). For example:

They may not care if the project is fundraised or funded through the athletic department but there's no question when they look at what their peers have they say we need this if we're going to be able to compete for a championship. (Lewis)

This competition is not exclusively for external competitors. Many coaches outside of the football and basketball programs view it as a competition for a smaller amount of monies available to "non-revenue programs". This can create an environment where the athletic director and development office decide to promote a facility project for one non-revenue program, and the coaches in other non-revenue programs feel slighted. One athletic fundraiser (Shawn) provided an example of internal fighting between non-revenue programs:

So, here's an example. Softball and track and field have gotten $\$ 70$ million worth of construction going on out there. Soccer is right next door to them. The soccer coach tweeted out a picture of the facilities, and said, “There's $\$ 70$ million worth of construction going on out here, people." That was all they said. Pretty passive-aggressive. And, I understand they said what they said. [The soccer program] worked pretty hard to raise money on their own. Those other two really haven't done any fundraising. They've done a lot of complaining. [Soccer has] been proactive [in self-fundraising], they [track and field] haven't. Now, they're [track and field] getting $\$ 70$ million worth of construction, and [soccer is] still in their facility.

This internal "cannibalism" between Olympic sports provides an example of how athletic department decision-making creates pressure and an unhealthy competition between the department's Olympic sport programs. They know football and men's basketball are going to get many of their projects prioritized over their own, but they find it especially hurtful when other non-revenue programs are given preference over their own program. 


\section{Title IX}

Trickle-down economics. When discussing the impact of Title IX on athletic fundraising, participants surprisingly viewed the legislation through the lens of football and men's basketball. Many of them took an approach akin to an ill-fated economic theory from the 1980's known as "trickle-down economics". The athletic fundraisers believed that the best way to solve Title IX was having a successful football and men's basketball program. This perspective stemmed from the belief these programs would increase revenue coming into the athletic department, corresponding with greater funding available for all varsity sports: "they understand that if football is doing well, then everybody will be doing well" (Luke). The fundraisers' view was that football and men's basketball provide funding across all programs, thereby requiring prioritization. Such a prioritization would help alleviate any Title IX concerns because the athletic department would have more funding: "Everywhere you go, football pays most of the bills, then basketball revenue pretty much picks up the rest. And you're lucky if you break even or make a little money on any other sport" (Brandon). Going further, one fundraiser claimed that Olympic sports should be the "biggest cheerleaders" of the football program:

At the same time, our Olympic sports should be the biggest cheerleaders for our football and basketball programs because the more successful a football program is, more revenue is realized and more revenue opportunities for tennis and golf and baseball and those type of sports. And I think for the most part, everybody gets that. In our athletic department these are our priorities and this is because we need football to benefit all of our sports. (George)

These findings report that athletic fundraisers not only believe having a successful football and men's basketball program helps Title IX concerns and fundraising for other varsity sport programs, but those programs should also buy into this model and be supportive of football and men's basketball, as these programs allow other sports to exist and potentially flourish.

"Title IX is a problem". Title IX was also perceived as a troublesome component of the athletic fundraiser's profession. The athletic fundraiser, and other internal stakeholders, have long-term plans on how to improve the athletic department, but expressed that Title IX can become a constraint on these plans, legally requiring them to prioritize underserved programs even if they prefer other projects. One athletic fundraiser gave an example of how their newly hired athletic director had to address Title IX concerns first, even though they wanted to kickstart facility improvements for football:

Some of those things could be driven based on Title IX issues. For example we had, when [athletic director] started here, priority number one was football. When he was hired it was to fix football. But when he got here he discovered that our facilities were some of the worst facilities in the country. And we had Title IX issues. So we had to direct our attention to building a new soccer facil- 
ity for our women's soccer. A new softball facility, a new tennis facility. All for women's sports, non-revenue sports. And so to make sure that we are compliant with Title IX, so at that point we were really focusing and really putting our attention to only those projects and really we're not actively fundraising for football or basketball at that point because we had to get those things addressed before we could turn our attention to our revenue sports. (George)

Another theme was that consideration for non-revenue programs only occurred once the situation became a legal issue under Title IX. Athletic fundraisers continued to prioritize certain sports, especially male sports, until they were notified that support was needed for their corresponding sports, often female sports, in order to avoid Title IX legal issues. Only when there were legal considerations did the athletic fundraisers, and subsequently the athletic department, start considering projects for these other programs: "Softball [facility] is so bad, and they have had success. We need to do something for them. Softball has also been a Title IX issue. Baseball, their equivalency sport, got a [over \$20 million] brand new stadium in 2012" (Shawn).

Others went further, mentioning how Title IX was stopping them from securing monies from top-level donors. For example: "There's a guy here in [redacted] that if we had track and field, we'd probably get five million dollars from him. But that takes us out of balance with gender equity and Title IX" (Robert). These responses showcase how athletic fundraisers often perceive Title IX as a hindrance to their profession and to the athletic department. Instead of viewing Title IX as a way to increase facilities available to many female sports and male, non-revenue programs, they are viewed as a deterrent for continuing the facility projects designed to improve the university's football and men's basketball programs.

Different standards for new facilities. Unlike football and men's basketball, other sports were required to share any facility improvements with other programs. Athletic fundraisers spoke of seeking facility improvements with multi-use facilities. These multi-use facilities were often targeted to sports besides football and men's basketball, who were able to get state-of-the-art facilities that would not be accessible to other varsity sport programs. Multi-use facilities do provide future cost reductions for the athletic department, as a multi-use facility provides benefits for multiple sports without having to create a facility for each sport, but athletic fundraisers often viewed it as a way for non-football programs to not distract the football student-athletes and maximize the availability of the premier facility to the football program. An example from one of the participants:

And realistically, our coaches are very smart about how they do things. One thing that part of our master plan is to build an Olympic sport weight room for all of our Olympic sports. Well, that will be priority number one because that's going to affect 12 sports compared to just affecting one sport with something else. So they understand that. They're all going to reap benefits from that. And while the Olympic sport weight room may not directly affect football, indirectly it'll affect football because it'll mean that less people are using their weight 
room because they have their own weight room so the golf team may not be over there using their weight room from 6 to 7:00 in the morning and it'll free up more time over there for them. So it has a direct effect on everybody (Luke).

In other instances, it was Olympic sports getting a facility handed down to them from the football program, who were being prioritized for a newer facility. This would mean football would maintain exclusive access to the new facility, but many of the other sports would "upgrade" to the facility that was being replaced: "When football vacates, call it 15 offices, the use of the weight room, use of the training room, use of academic tutoring services over there and the academic center over there. Now you repurpose that space for other programs" (Robert).

In addition to often having to share new or re-purposed facilities, athletic fundraisers often talked about the willingness to split donations from prominent donors that wanted to support projects outside of football and basketball. This was not perceived as a conscious decision by the athletic fundraiser, but any time they mentioned a specific sport program regarding joint asks, an athletic and academic donation, they always invoked an Olympic sport: "A lot of them will say, 'It wouldn't have been possible without the hockey program. It wouldn't have been possible without the business school.' I think that's certainly the case" (Derek). Another fundraiser spoke of a collaboration between women's soccer, baseball, and the university's business school for an endowed scholarship. Athletic fundraisers did provide one avenue for non-football and men's basketball programs to become prioritized for facility improvements - program success. This was an extremely high bar for programs to reach, as participants often described program success as being one of the recent best programs in your sport in order to demand new or improved facilities. For one women's program, this required winning two of the previous three national championships:

I mean it gets (sic) you want to help out the programs that are being successful and you want to build on that momentum. I mean [women's spring sport] has won two out of the last three national championships so this spring we just announced that we're going to renovate their stadium and build some more seats and stuff like that. It kind of feeds itself a little bit. I mean they've been successful, so we've had great attendance and we've had sellouts so that's forcing to look at our stadium and see how we can build more seats (Scott).

Another example:

Baseball's been in the College World Series [frequently recently]. There's a better than not chance that they're gonna get there and win it at some point. If we win with the national championship in baseball, guarantee you baseball coaches are gonna be knocking on the AD's door going, 'How about we redo this baseball stadium in a large way?' Then for two reasons, the appetite to do it will be there. Number one because we're winning and we want to keep the guy. Number 
two is because the way our stadium's configured, we can very easily wipe everything from the concourse level up out and start over with some suites. We have suites at the baseball stadium now, but we need more. We got demand for it, but we just don't have them available, and some other improvements (Donavan).

This level of success limits facility improvements to only teams who win national championships, an almost impossible bar for many programs, especially those lacking in program history. These challenges, requiring to be a "cheerleader" for football, only getting new facilities when you are legally required, having to share hand-medown facilities with other sports, having to split donations with academic programs, and needing to win a national championship in order to prioritize facility improvements, showcase the incredibly high standards and diluted benefits that are provided to non-revenue sport programs when compared to football and men's basketball.

\section{Discussion}

The purpose of this paper is to explore the perception of Title IX by athletic department fundraisers. Specifically, we examine how athletic fundraisers work with prominent athletic donors in guiding or restricting their donation towards specific sport programs or prioritized projects. Previous studies have investigated the challenges faced by Olympic sports, particularly women sports, in trying to achieve equal footing with football and men's basketball within college sports (Francis, 2016; Rubin \& Lough, 2015). Within that literature, there is a need to examine areas of resource distribution that are often overlooked in the implementation of Title IX, such as fundraising. In the previous section, responses from athletic fundraisers were categorized by themes stemming from the Gioia methodology. These themes sought to identify the effect of Title IX on their roles and potential barriers placed on Olympic sports, especially women's sports related to fundraising.

First, fundraisers described their discussions with coaches and how those interactions were framed within a distributive justice approach as a means for defending their requests. Athletic fundraisers discussed how every coach has "big picture" items they want the athletic department to prioritize to improve their program, such as improved practice facilities. Very few of these projects are chosen as priorities, therefore coaches would frame the importance of their requests through a couple different approaches. First, coaches would keep close tabs on the facility upgrades secured by their competitors, such as a Big Ten women's soccer program seeing another Big Ten women's soccer program securing renovations for its locker room. Once another program announced these improvements, the coach would frame their request of improvements as a need, believing they needed their requests approved in order to maintain the probability of success against a competitor that had already started its renovations and would soon reap benefits in the form of improved player performance, recruiting, analytics, etc. These findings extend Mahony et al.'s (2005) findings about need being defined as competing successfully. They reported how budget allocations were consistently monitored and argued as a need. 
Fundraisers also mentioned how coaches paid attention to initiatives that were approved for other Olympic sport programs instead of their own. With coaches sensing a limited amount of funding initiatives available to non-football/men's basketball programs, it created a hostile environment where one program was able to secure a funding campaign to improve their program but ended up generating disdain from other Olympic sport programs whose requests were not chosen. This finding helps extend the concept of equity by illuminating possible negative consequences. Coaches within Olympic sports feel increased pressure within an equity approach due to the decreased funding available. This pressure manifests itself with passive aggressive behavior or comparison between programs that may erode organizational culture (Jayakumar \& Comeaux, 2016). These negative consequences are unfortunate managerial implications for using an equitable approach. Implementing an equality approach or finding a way to alleviate this passive aggressive behavior between programs, such as increasing fundraising initiatives for non-football/men's basketball programs, would be recommended alternatives for managers. This lack of funding for sports outside of football and men's basketball, and the in-fighting to secure these limited funds, also creates an unfair environment for women's sports. The majority of fundraising and projects are predisposed to two men's sports, therefore creating a lack of resources for women's sports due to persistent beliefs across the athletic development offices and athletic departments interviewed for this study that football and men's basketball need to be prioritized. With athletic fundraising falling within a "gray area" of Title IX, athletic departments seem to seize this opportunity to prioritize football and men's basketball by constructing new facilities or renovating older ones. This would allow the athletic department to use the old facility, previously used by football, to now be used by Olympic sports to share a common facility, complying with Title IX by the law, but not the spirit.

\section{Title IX Implications}

Results on fundraisers directly responding to the influence of Title IX on their role helps scholars better understand the influence of Title IX on fundraising initiatives but also provides theoretical contributions for distributive justice. The overwhelming view of Title IX was from the perspective of equity; that football and men's basketball should be given a priority for incoming fundraising dollars and prioritized facility projects since they bring in the great majority of revenue. This perception was justified because fundraisers believed having a successful football and men's basketball program would increase the revenue for the athletic department, which would then provide a bigger pool of money that could be split up among the other programs. One fundraiser summarized this cycle by saying Olympic sport programs "should be the biggest cheerleaders for our football and basketball programs" (George). These findings further extend our understanding of equity and the justification of its use, with managers or decision-makers justifying this approach as a round-about way of providing the majority of available monies to football and men's basketball with the incentive that if they are successful it will lead to more monies for other sport programs further down the road. 
This belief may also be rooted within fundraisers' belief of need, that most college athletic departments invest additional millions of dollars in their football program rather than in other sports because other athletic departments do the same and believe that a reduction in financial support will lead to a decrease in on-field success (Mahony et al., 2005). This argument becomes untenable within an equity approach, especially using the fundraisers' argument here that non-football/men's basketball programs should be supportive of football and men's basketball receiving the majority of funding requests. This argument is dependent on either achieving or maintaining success in football and men's basketball, which is bound by binary results that will leave the same amount of losing programs and winning programs, yet there are ever-increasing costs for new facilities, coaching salaries, and auxiliary spending that eliminates the benefit of supporting these programs. It also requires a coach to take an unnatural perspective of putting the resources needs of other programs over their own. With coaches in a working environment that have extreme pressure, endless hours, and risk of being fired if their team performs poorly (Bruening \& Dixon, 2007; Hancock et al., 2019; Taylor, Huml, \& Dixon, 2019), this perspective becomes an impossible request.

Title IX also functioned as motivation, albeit a legal motivation, for athletic departments to utilize an equality approach. Highlighting this issue was the specific quote from one fundraiser regarding the newly-hired athletic director having to deny his desire to focus on football to begin improving facilities in other sports due to Title IX compliance. These findings progress our theoretical understanding of the equality approach within distributive justice. Administrators may choose an equality approach based on fear of legal ramifications, not based on their beliefs of what would serve the best interests of their department. There are both positives and negatives for this finding. A positive is that Title IX is providing for women as intended. Athletic directors and university decision-makers may want to continue increasing their investment into football and men's basketball programs. Title IX requires these important stakeholders to reconsider certain facility projects to ensure similar facilities and funding is provided to female sports. One negative is that schools are likely to pursue an equality approach that only achieves a bare minimum by legal standards. Coaches outside of football and men's basketball are recommended to understand Title IX and use their knowledge of the statute to their maximum benefit when making requests to their athletic director and fundraising office.

Lastly, fundraisers spoke about how once a non-football/men's basketball program achieved an elite level of success, such as winning a national championship, their facility requests were taken more seriously and provided a level of priority similar to "revenue-generating sports." Surprisingly, the fundraisers did not consider this change of resource distribution from the perspective of equality, but from need. They viewed the facility improvements for the program as a necessity to (1) keep the coach, who has now become a valued asset, and (2) necessary to maintain the program's contention for national championships. This was disappointing for a few reasons. First, unlike the low bar for football/men's basketball programs to achieve in order to be prioritized for big-ticket fundraising initiatives, other sports were ex- 
pected to win national championships to become prioritized, creating an extremely unfair incentive structure for other sport programs. Second, the fundraiser projected the athletic department's view as a need approach, believing that it was the coach whom was the department's asset. Therefore, resources needed to be provided in order for the coach to stay and maintain success at their current school, in fear of being lured to another school with improved resources, therefore projecting the perspective of the coach being the important asset, not the program.

\section{Limitations \& Future Recommendations}

While this study provides unique contributions to the distributive justice and Title IX literature, there are limitations of the study and application. Data collected for this study were collected during a period of six months and comes from a cross-sectional approach, limiting its application to other areas within fundraising, distributive justice, and Title IX governance. Data were collected from athletic fundraisers within college sport, a context and relationship that may not be replicated within professional and amateur sports, therefore not generalizable within those levels. Lastly, data were collected from predominantly Power Five athletic departments, limiting their generalizability to lower-level athletic departments.

Findings from this study provide avenues for future scholarship. Responses from fundraisers within this study helped us better understand the parameters and application of the equity application of resource distribution. Coupled with previous findings on the need approach (Mahony et al., 2005), future research would be best used to examine greater details on how decision-makers define and apply an equality approach for resource distribution. Also, the influence of fundraisers on donors, and the affluence possessed by donors, provides an opportunity to explore the dynamic between fundraiser and donor to extend theoretical underpinnings within certain business models, such as stakeholder or stewardship theory. The authors were only able to complete interviews with two women working within athletic development. While this study was not particularly looking for participants based on gender, the lack of female participants may speak to the lack of female representation within athletic development. A future study examining this phenomenon is needed. Certain athletic departments, such as the University of Oregon, have implemented permanent athletic fundraising initiatives for their women sports programs. A future study examining the impact of these programs would be a unique contribution to the field and help provide insight into effective development initiatives for women's sport. We believe this study provides a unique contribution to the field by providing insight into the application of distributive justice within fundraising outlets. With fundraisers influencing donors to support prominent sports such as football and men's basketball, they create a system that is restricted to an equity approach unless certain thresholds are reached, such as a nonrevenue program winning national championships or the need to comply with Title IX. 


\section{References}

Bruening, J. E., \& Dixon, M. A. (2007). Work-family conflict in coaching II: Managing role conflict. Journal of Sport Management, 21, 471-496.

Brunette, C., Vo, N., \& Watanabe, N. M. (2017). Donation intention in current students: An analysis of university engagement and sense of place in future athletic, academic, and split donors. Journal of Issues in Intercollegiate Athletics, 10, 78-100.

Cheslock, J. J., \& Knight, D. B. (2015). Diverging revenues, cascading expenditures, and ensuing subsidies: The unbalanced and growing financial strain of intercollegiate athletics on universities and their students. The Journal of Higher Education, 86, 417-447.

Cooky, C., Messner, M. A., \& Musto, M. (2015). “It’s dude time!” A quarter century of excluding women's sports in televised news and highlight shows. Communication \& Sport, 3, 261-287.

Cunningham, G. B., \& Sagas, M. (2005). Access discrimination in intercollegiate athletics. Journal of Sport and Social Issues, 29, 148-163.

Deutsch, M. (1975a). Distributive justice. New Haven, CT: Yale University Press.

Deutsch, M. (1975b). Equity, equality, and need: What determines which value will be used as the basis of distributive justice? Journal of Social Issues, 31, 137-149.

Dixon, M. A., Turner, B. A., Pastore, D. L., \& Mahony, D. F. (2003). Rule violations in intercollegiate athletics: A qualitative investigation utilizing an organizational justice framework. Journal of Academic Ethics, 1, 59-90.

Edwards, A. R. (2010). Why sport? The development of sport as a policy issue in Title IX of the education amendments of 1972. Journal of Policy History, 22, 300-336.

Flyvbjerg, B. (2006). Five misunderstandings about case-study research. Qualitative Inquiry, 12, 219-245.

Francis, L. (2016). Title IX: An incomplete effort to achieve equality in sports. Journal of the Philosophy of Sport, 43, 83-99.

Frank, R. H. (2004). Challenging the myth: A review of the links among college athletic success, student quality, and donations. Miami, FL: Knight Foundation Commission on Intercollegiate Athletics.

Friedman, M. T., Parent, M. M., \& Mason, D. S. (2004). Building a framework for issues management in sport through stakeholder theory. European Sport Management Quarterly, 4, 170-190.

Gioia, D. A., \& Chittipeddi, K. (1991). Sensemaking and sensegiving in strategic change initiation. Strategic Management Journal, 12, 433-448.

Gioia, D. A., Corley, K. G., \& Hamilton, A. L. (2012). Seeking qualitative rigor in inductive research: Notes on the Gioia methodology. Organizational Research Methods, 16, 15-31.

Gioia, D. A., \& Thomas, J. B. (1996). Identity, image and issue interpretation: Sensemaking during strategic change in academia. Administrative Science Quarterly, 41, 370-403. 
Gladden, J. M., Mahony, D. F., \& Apostolopoulou, A. (2005). Toward a better understanding of college athletic donors: What are the primary motives? Sport Marketing Quarterly, 14, 18-30.

Grimmett-Norris, R. (2015). Roadblocks: Examining Title IX \& the fair compensation of Division I intercollegiate student-athletes. Saint Louis University Public Law Review, 34, 435-464.

Hancock, M. G., Balkin, R. S., Reiner, S. M., Williams, S., Hunter, Q., Powell, B., \& Juhnke, G. A. (2019). Life balance and work addiction among NCAA administrators and coaches. The Career Development Quarterly, 67, 264-270.

Huml, M. R., Pifer, N. D., Towle, C., \& Rode, C. R. (2019). If we build it, will they come? The effect of new athletic facilities on recruiting rankings for power five football and men's basketball programs. Journal of Marketing for Higher Education, 29, 1-18.

Hums, M. A., \& Chelladurai, P. (1994). Distributive justice in intercollegiate athletics: The views of NCAA coaches and administrators. Journal of Sport Management, 8, 200-217.

Jayakumar, U. M., \& Comeaux, E. (2016). The cultural cover-up of college athletics: How organizational culture perpetuates an unrealistic and idealized balancing act. The Journal of Higher Education, 87, 488-515.

Ko, Y. J., Rhee, Y. C., Walker, M., \& Lee, J. H. (2014). What motivates donors to athletic programs: A new model of donor behavior. Nonprofit and Voluntary Sector Quarterly, 43, 523-546.

Kim, S., Andrew, D. P. S., Mahony, D.F., \& Hums, M. A. (2008). Distributive justice in intercollegiate athletics: Perceptions of student athletes. International Journal of Sport Management, 9, 379-393.

Longman, J. (2019, December 3). A welcome funding source for college athletics: Women investing in women's sports. The New York Times. Retrieved from https://www.nytimes.com/2019/12/03/sports/women-donations-college-athletics.html

Mahony, D. F., \& Pastore, D. (1998). Distributive justice: An examination of participation opportunities, revenues, and expenses at NCAA institutions - 19731993. Journal of Sport and Social Issues, 22, 127-152

Mahony, D. F., Hums, M. A., \& Riemer, H. A. (2002). Distributive justice in intercollegiate athletics: Perceptions of athletic directors and athletic board chairs. Journal of Sport Management, 16, 331-356.

Mahony, D.F., Gladden, J.M., \& Funk, D.C. (2003). Examining athletic donors at NCAA Division I institutions. International Sports Journal, 7, 9-27.

Mahony, D. F., Hums, M. A., \& Riemer, H. A. (2005). Bases for determining need: Perspectives of intercollegiate athletic directors and athletic board chairs. Journal of Sport Management, 19, 170-192.

Mahony, D. F., Riemer, H. A., Breeding, J. L., \& Hums, M. A. (2006). Organizational justice in sport organizations: Perceptions of college athletes and other college students. Journal of Sport Management, 20, 159-188. 
Martinez, J. M., Stinson, J. L., Kang, M., \& Jubenville, C. B. (2010). Intercollegiate athletics and institutional fundraising: A meta-analysis. Sport Marketing Quarterly, 19, 36-47.

Messner, M. A., \& Solomon, N. M. (2007). Social justice and men's interests: The case of Title IX. Journal of Sport \& Social Issues, 31, 162-178.

NCAA. (2018a). 14-year trends in Division I athletics finances. Indianapolis, IN: Author.

NCAA. (2018b). NCAA Division I Manual. Indianapolis, IN: Author.

Office for Civil Rights, U.S. Department of Health, Education, and Welfare (1979). "A Policy Interpretation: Title IX and Intercollegiate Athletics." Federal Register 44 (239). Retrieved from http://www2.ed.gov/about/offices/list/ocr/docs/ t9interp.html

Park, C., Jae Ko, Y., Kim, H. Y., Sagas, M., \& Eddosary, M. (2016). Donor motivation in college sport: Does contribution level matter? Social Behavior and Personality, 44, 1015-1032.

Patrick, I. S. C., Mahony, D. F., \& Petrosko, J. M. (2008). Distributive justice in intercollegiate athletics: An examination of equality, revenue production, and need. Journal of Sport Management, 22, 165-183.

Rubin, L. M., \& Lough, N. L. (2015). Perspectives of Title IX pioneers: Equity, equality and need. Journal of Intercollegiate Sport, 8, 109-130.

Sanderson, A. \& Siegfried, J. (2017). The National Collegiate Athletic Association cartel: Why it exists, how it works, and what it does. Review of Industrial Organization, 52, 185-209.

Sparvero, E. S., \& Warner, S. (2013). The price of winning and the impact on the NCAA community. Journal of Intercollegiate Sport, 6, 120-142.

Stinson, J. L., \& Howard, D. R. (2004). Scoreboards vs. mortarboards: Major donor behavior and intercollegiate athletics. Sport Marketing Quarterly, 13, 129-140.

Stinson, J. L., \& Howard, D. R. (2007). Athletic success and private giving to athletic and academic programs at NCAA institutions. Journal of Sport Management, 21, 235-264.

Stinson, J. L., \& Howard, D. R. (2010). Intercollegiate athletics as an institutional fundraising tool: An exploratory donor-based view. Journal of Nonprofit \& Public Sector Marketing, 22, 312-335.

Tax Cuts and Jobs Act of 2017, Pub. L. No. 115-97, 131 Stat. 2054 (2017).

Taylor, E. A., Huml, M. R., \& Dixon, M. A. (2019). Workaholism in sport: A mediated model of work-family conflict and burnout. Journal of Sport Management, $33,249-260$.

Thelin, J. R. (2000). Good sports? Historical perspective on the political economy of intercollegiate athletics in the era of Title IX, 1972-1997. The Journal of Higher Education, 71, 391-410.

Title IX, 20 U.S.C. § 1681 (1972).

Törnblom, K. Y., Jonsson, D., \& Foa, U. G. (1985). Nationality, resource class and preferences among three allocation rules: Sweden vs. USA. International Journal of Intercultural Relations, 9, 51-77. 